\title{
Risk Factors Related to the Crystalluria Case among Workers at Welding Department Of Automotive Industry X Jakarta
}

\author{
Fitriyani $^{1}$, Veri Wardi ${ }^{2}$ \\ \{fitriyani@ph.unand.ac.id ${ }^{1}$,veri.wardi@bps.go.id ${ }^{2}$ \}
}

Faculty of Public Health, Andalas University, Padang, Indonesia ${ }^{1}$, Department of Distribution, Statistics Indonesia, Padang, Indonesia ${ }^{2}$,

\begin{abstract}
The case of crystalluria occurs in almost all types of work. However, its prevalence has not been recorded since crystalluria is the early indicator for urolithiasis and urinary tract disorder. Crystalluria found either in person in normal condition or disorder. In normal people, the crystalluria will disappear within a few days if the person is controlling and avoiding the risk factors. This study aims to look at the relationship between job factors and individual factors with crystalluria cases in welding workers. The study's sample was 220 workers out of 1,253 population at the Welding Department Industry Automotive X Jakarta. Primary data collection was done through a questionnaire, interviewed, measured body weight before and after work, measured of wet and bulb globe temperature (WBGT) in the workspace. Then, secondary data collection was done through employees' medical checkup records (MCU). Univariate and bivariate analyses were used by chi-square and independent T-test. The research found that the significant risk factors to the occurrence of crystalluria were body weight $(\mathrm{OR}=1,38 ; 95 \% \mathrm{CI}=1,09$ to 1,92$)$, the balance of body fluids ( $\mathrm{OR}=5,77 ; 95 \% \mathrm{CI}=2,79$ to 11,33$)$, and high purine foods consumption (P-value of 0,04; SD: 237,1). So, the recommendation for controlling risk factors of crystalluria is increasing physical activity, hydration, and dietary adjustments.
\end{abstract}

Keywords: crystalluria; urine crystallization; body weight; body fluids; purine

\section{Introduction}

Urinary crystals, or in medical known as crystalluria was the discovery of the crystals in the urine as sediment. This condition can be seen from the urine analysis in the clinical laboratory. Urine crystals are found both in people under normal conditions and in the presence of interference. For a normal person, crystals in the urine may disappear within a few days if the person has been avoiding the main cause of crystal appearance. Then, crystals of urine are one of the biomarkers that urine has too saturated (supersaturation) due to the metabolic system abnormalities. The presence of a disease, especially in the excretory system kidney and urinary tract (e.g., urinary tract infections and kidney stones); consumption of a particular food; or effect of excessive long-term consumption of drugs [1].

The exact number case of crystalluria was unrecorded due to urine crystals is an early indicator before the advent of stones in the urinary tract (urolithiasis). So, it was often neglected. In the United States in 2014, cases of urinary tract stones were reported around 36 cases per 100,000 population per year. In Indonesia, the incidence of urinary tract stones has 
not been recorded with certainty but was estimated 170,000 cases per year. Moreover, in Indonesia, the most common cause of kidney failure was due to urinary tract infections and stones in the urinary tract where both can be prevented when the first indicator (urine crystals) has been detected [2].

According to the Medical Check-Up (MCU) which is routinely done every 2 years In the automotive industry X Jakarta, the result from last three times checked (the year 2011, 2013 , 2015) was found that the case numbers of urine crystals are always in the second position (after caries gangrene Radix). Then, from all departments in the industry, the welding department has the highest prevalence cases for crystalluria, which amounted to $27.5 \%$, or about 345 people out of 1,253 workers.

\section{Method}

The study design used mixed methods (mixed methods) with sequential exploratory strategy. The sequential exploratory strategy is the method of research that combines the qualitative research method in the first stage and quantitatively in the next stage. Qualitative methods used to discover the hypothesis on the specific cases or limited sample and quantitative methods used to test the hypothesis found from qualitative research on the wider population. The study was conducted at the same time, collected by the observation momentary or within a certain period and only one time observations during the study research. The sample research respondent is 220 workers from the 1.253 population at the welding department automotive industry X Jakarta.

\section{Results}

Respondents who state as positive crystalluria is having positive $(+)$ calcium oxalate and/or uric acid in the urine. It was known from the urinalysis result at MCU 2015 reports. The urinalysis results have been distributed to each worker. The respondents should have known that he was crystalluria positive or not.

Based on the MCU 2015 report, 86 respondents (39.1\%) crystalluria positive, but only 37 respondents $(16.8 \%)$ were aware that he was suffering from crystalluria. So, 49 people did not realize that he had crystalluria. It means, most of the respondents did not understand the terms contained in their MCU report. For example, the term of crystalluria in an MCU report was positive $(+) \mathrm{Ca}$ oxalate and/or uric acid. In addition, there are also other urine parameters on the results of urinalysis MCU, for example, amorphous $(+)$, protein $(+)$ to protein $(+++)$. For that reason, to increase the worker's awareness about crystalluria, the corporate should be given a more detailed explanation to workers. 
Table 1. Overview Crystalluria Cases Comparison between Respondent's Questionnaire Answers and MCU 2015 Report

\begin{tabular}{lcccc}
\hline \multirow{2}{*}{ Crystalluria } & \multicolumn{2}{c}{ MCU 2015 Report } & \multicolumn{2}{c}{$\begin{array}{c}\text { Respond's Questionnaire } \\
\text { Answers }\end{array}$} \\
\cline { 2 - 5 } & Freq $(\mathrm{n})$ & $\%$ & Freq $(\mathrm{n})$ & $\%$ \\
\hline Yes & 86 & 39,1 & 37 & 16,8 \\
No & 134 & 60,9 & 183 & 83,2 \\
\hline Total & 220 & 100 & 220 & 100 \\
\hline
\end{tabular}

\section{Factors Related to Crystalluria}

To see the relation between the independent variables (job factors and individual factors) with the dependent variable (crystalluria) was analyzed with bivariate analysis using the chisquare test and independent T-test. Data distribution is normally based on normality test results.

\section{Individual Factors Related to Crystalluria}

The variables of individual factor are age; the history of another abnormality urine sediment (exclude crystalluria); the history of drug consumption that contains antimicrobial, antiviral agent \& diuretic; heredity; physical activity; body mass index; mineral water consumption; body fluid balance; urination frequency; and food consumption.

From 10 variables of individual factor, 3 variables have a statistically significant related to crystalluria case, there are body mass index $(\mathrm{P}$-value $=0.031$ and $\mathrm{OR}=1.38)$; body fluid balance $(\mathrm{P}$-value $=0.041$ and $\mathrm{OR}=5.77)$; and foods consumption with high purine $(\mathrm{P}$-value of 0.040). (Table 6)

The balanced weight is influenced by a healthy diet, sufficient physical activity, heredity (genetics), and the amount of sleep [21]. The research found for physical activity and heredity didn't have a meaningful relationship with the case of crystalluria. So, workers need to adjustment their healthy diet and improve their total rest. For workers, meals during work hours need to be considered and managed well by the company because the company provides facilities for lunch and overtime meals and dinner for night shift workers.

The research found that crystalluria related to an imbalance body fluid variable. Measurement of body fluid balance is done by calculating the difference in weight when the workers before work and after work. The results are many workers had lost weight. It ranged from $0.5 \mathrm{~kg}-2.2 \mathrm{~kg}$. (Tabel 6). Moreover, imbalanced body fluid can be associated with an insufficient number of drinking water per day (Table 2). The research found that respondents with crystalluria $(+)$ are $40,6 \%$ lack of mineral water consumption amount, and interval of drinking time was bad also because of its takeover than 2 hours. Most respondents' reasons are the distance of the working area and dispenser is too far and drinking water in the weird workplace taste (Table 3). 
Table 2. Respondents Mineral Water Drinking Habits a Day at Welding Automotive X Jakarta 2016

\begin{tabular}{|c|c|c|c|c|c|c|c|}
\hline & \multirow{2}{*}{ Categories } & \multicolumn{4}{|c|}{ Crystalluria } & \multirow{2}{*}{ Total } & \multirow{2}{*}{$\%$} \\
\hline & & $(+)$ & $\%$ & $(-)$ & $\%$ & & \\
\hline \multirow{2}{*}{$\begin{array}{l}\text { Amount of Mineral } \\
\text { Water Consumption }\end{array}$} & Less & 76 & 40,6 & 111 & 59,4 & 187 & 100 \\
\hline & Enough & 10 & 30,3 & 23 & 69,7 & 33 & 100 \\
\hline \multirow{2}{*}{$\begin{array}{l}\text { Drinking time } \\
\text { interval }\end{array}$} & Over 2 Hours & 45 & 42,1 & 62 & 57,9 & 107 & 100 \\
\hline & Less 2 Hours & 41 & 36,3 & 72 & 63,7 & 113 & 100 \\
\hline
\end{tabular}

Table 3. Respondents Reasons for Less Drinking Per Day in the Working Area at Welding Automotive X Jakarta 2016

\begin{tabular}{llcccccc}
\hline \multirow{2}{*}{ Reason } & \multirow{2}{*}{ Categories } & \multicolumn{9}{c}{ Crystalluria } & \multirow{2}{*}{ Total } & \multirow{2}{*}{$\%$} \\
\cline { 3 - 6 } & & $(+)$ & $\%$ & $(-)$ & $\%$ & & \\
\hline Glass or dispenser & Yes & 24 & 49 & 25 & 51 & 49 & 100 \\
dirty/weird taste & No & 62 & 36,3 & 109 & 63,7 & 171 & 100 \\
$\begin{array}{l}\text { Distance of working area } \\
\text { and water dispenser }\end{array}$ & Yes & 41 & 36,9 & 70 & 63,1 & 111 & 100 \\
& No & 45 & 41,3 & 64 & 58,7 & 109 & 100 \\
Workload & Yes & 21 & 46,7 & 24 & 53,3 & 45 & 100 \\
$\begin{array}{l}\text { Forbidden to bring } \\
\text { drinking water to the work }\end{array}$ & No & 65 & 37,1 & 110 & 62,9 & 175 & 100 \\
area & Yes & 11 & 33,3 & 22 & 66,7 & 33 & 100 \\
& No & 75 & 40,1 & 112 & 59,9 & 187 & 100 \\
\hline
\end{tabular}

Due to complaints about the weird taste of drinking water in the work area, been performed testing of mineral water in the area complained. The measurements used calibrated Spectrophotometer HACH DR / 2700. The results were drinking water had a chlorine content amount of $3.54 \mathrm{mg} /$ liter. (Table 4). This amount exceeds the threshold limit value, which is suggested in SNI 01-3553-2006; the maximum amount is $0.1 \mathrm{mg} /$ liter [22]. The high free chlorine $(\mathrm{Cl} 2)$ in the drinking water of this in humans could be at risk of irritation of the esophagus, burning sensation in the mouth and throat, sores in the organ tissue (tissue injury), and acute asthma. Whereas in mice experiments, $\mathrm{Cl} 2$ consumption in a long time causes a decrease in saliva glands, kidney weight loss, and potential leukemia [23]. Until these studies are complete on the date of June 15, 2016, this finding is still under investigation by an EHS Division Automotive X Jakarta, so the basic cause still unknown.

Table 4. Result of Physical and Chemistry Analysis for Mineral Water at Welding Automotive X Jakarta 2016

\begin{tabular}{lccc}
\hline \multicolumn{1}{c}{ Parameter } & Unit & Tested Result & $\begin{array}{c}\text { SNI 01-3553-2006 } \\
\text { Recommendation }\end{array}$ \\
\hline Smell & - & Smelly & No Smell \\
Flavor & - & Weird & Normal \\
pH & & 7,59 & $6,0-8,5$ \\
Turbidity & NTU & 0,181 & Max. 15 \\
Total dissolved solids & mg/liter & 174 & Max. 500
\end{tabular}




\begin{tabular}{llcc}
\hline Chloride $(\mathrm{Cl})$ & $\mathrm{mg} /$ liter & 4,3 & Max. 250 \\
Organic substances $(\mathrm{KMnO} 4)$ & $\mathrm{mg} / \mathrm{liter}$ & 0,00 & Max. 0,1 \\
Sulfate $(\mathrm{SO} 4)$ & $\mathrm{mg} /$ liter & 8 & Max. 200 \\
Ammonium $(\mathrm{NH} 4)$ & $\mathrm{mg} / \mathrm{liter}$ & 0,001 & Max. 0,15 \\
Iron $(\mathrm{Fe})$ & $\mathrm{mg} / \mathrm{liter}$ & 0,00 & Max. 0,1 \\
Nitrate $(\mathrm{NO} 3)$ & $\mathrm{mg} / \mathrm{liter}$ & 5,7 & Max. 45 \\
Nitrite $(\mathrm{NO} 2)$ & $\mathrm{mg} / \mathrm{liter}$ & 0,003 & Max. 0,005 \\
Fluoride $(\mathrm{F})$ & $\mathrm{mg} / \mathrm{liter}$ & 0,39 & Max. 1,0 \\
Copper $(\mathrm{Cu})$ & $\mathrm{mg} / \mathrm{liter}$ & 0,00 & Max. 0,5 \\
Cyanide $(\mathrm{CN})$ & $\mathrm{mg} / \mathrm{liter}$ & 0,049 & Max. 0,05 \\
Manganese $(\mathrm{Mn})$ & $\mathrm{mg} / \mathrm{liter}$ & 0,000 & Max. 0,05 \\
Chlorine $(\mathrm{Cl})$ & $\mathrm{mg} /$ liter & $\mathbf{3 , 5 4}$ & Max. 0,1 \\
\hline
\end{tabular}

Crystalluria is related to food consumption, especially foods containing high purine, high oxalate, diuretics, and salt. The research found, form the four categories of these foods. Statistically, high-purine foods had a meaningful relationship with the case of urine crystallization. Actually, consumption of high-purine food reached 163 times per month or about 5 times per day.

Table 5. Overview of Respondents Crystalluria Case Distribution Monthly

\begin{tabular}{|c|c|c|c|c|c|}
\hline Kind of Food & Crystalluria & Mean & $\begin{array}{c}\text { Std. } \\
\text { Deviation }\end{array}$ & $\begin{array}{c}\text { Std. Error } \\
\text { Mean }\end{array}$ & $\begin{array}{c}\text { P- } \\
\text { Value }\end{array}$ \\
\hline \multirow{2}{*}{ High Purine } & $(+)$ & 163 & 237.1 & 25.6 & \multirow{2}{*}{0,04} \\
\hline & $(-)$ & 122.2 & 95.6 & 8.3 & \\
\hline \multirow{2}{*}{ High Salt } & $(+)$ & 31.3 & 64.2 & 6.9 & \multirow{2}{*}{0,559} \\
\hline & $(-)$ & 27.1 & 40.8 & 3.5 & \\
\hline \multirow{2}{*}{ High Oxalate } & $(+)$ & 47.5 & 52.4 & 5.7 & \multirow{2}{*}{0,140} \\
\hline & $(-)$ & 38.5 & 37.7 & 3.3 & \\
\hline \multirow{2}{*}{ Diuretic } & $(+)$ & 48.1 & 46.1 & 5 & \multirow{2}{*}{0,226} \\
\hline & $(-)$ & 40.9 & 41.1 & 3.6 & \\
\hline
\end{tabular}


Table 6. Overview of Respondent's Individual Factors Distribution (age; the history of another abnormality urine sediment (exclude crystalluria); the history of drug consumption that contain antimicrobial, antiviral agent \& diuretic; heredity; physical activity; body mass index; mineral water consumption; body fluid balance; urination frequency)

\begin{tabular}{|c|c|c|c|c|c|c|c|c|c|}
\hline \multirow{3}{*}{ Variables from Individual Factor } & \multirow{3}{*}{ Categories } & \multicolumn{4}{|c|}{ Crystalluria } & \multirow{2}{*}{\multicolumn{2}{|c|}{ Total }} & \multirow{3}{*}{ P-value } & \multirow{3}{*}{ OR $95 \% \mathrm{Cl}$} \\
\hline & & \multicolumn{2}{|c|}{$(+)$} & \multicolumn{2}{|c|}{$(-)$} & & & & \\
\hline & & $\mathbf{N}$ & $\%$ & $\mathbf{N}$ & $\%$ & $\mathbf{N}$ & $\%$ & & \\
\hline \multirow{2}{*}{ Age } & $>=40$ tahun & 3 & 42,9 & 4 & 57,1 & 7 & 100 & \multirow{2}{*}{0,836} & 1,18 \\
\hline & $<40$ Years old & 83 & 39 & 130 & 61 & 213 & 100 & & $0,26-5,38$ \\
\hline \multirow{2}{*}{$\begin{array}{l}\text { History of another abnormalities urine } \\
\text { sediment (exclude crystalluria) }\end{array}$} & Yes & 39 & 43,8 & 50 & 56,2 & 89 & 100 & \multirow{2}{*}{0,236} & 1,39 \\
\hline & No & 47 & 35,9 & 84 & 64,1 & 131 & 100 & & $0,81-2,42$ \\
\hline \multirow{2}{*}{$\begin{array}{l}\text { history of drug consumption that contains } \\
\text { antimicrobial, antiviral agent } \& \text { diuretic }\end{array}$} & Yes & 5 & 50 & 5 & 50 & 10 & 100 & \multirow{2}{*}{0,469} & 1,59 \\
\hline & No & 81 & 38,6 & 129 & 61,4 & 210 & 100 & & $0,45-5,67$ \\
\hline \multirow{2}{*}{ Heredity } & Yes & 14 & 35 & 26 & 65 & 40 & 100 & \multirow{2}{*}{0,558} & 0,81 \\
\hline & No & 72 & 40 & 108 & 60 & 180 & 100 & & $0,4-1,65$ \\
\hline \multirow{2}{*}{ Physical activity } & Less & 13 & 34,2 & 25 & 65,8 & 38 & 100 & \multirow{2}{*}{0,498} & 0,78 \\
\hline & Enough & 73 & 40,1 & 109 & 59,9 & 182 & 100 & & $0,37-1,62$ \\
\hline \multirow{3}{*}{ Body mass index } & Over-Obes & 26 & 53,1 & 23 & 46,9 & 49 & 100 & \multirow{3}{*}{$\mathbf{0 , 0 3 1}$} & 1,38 \\
\hline & Underweight & 4 & 21,1 & 15 & 78,9 & 19 & 100 & & $1,09-1,92$ \\
\hline & Normal & 56 & 36,8 & 96 & 63,2 & 152 & 100 & & \\
\hline \multirow{2}{*}{ Mineral water consumption } & Less & 76 & 40,6 & 111 & 59,4 & 187 & 100 & \multirow{2}{*}{0,262} & 1,58 \\
\hline & Enough & 10 & 30,3 & 23 & 69,7 & 33 & 100 & & $0,71-3,5$ \\
\hline \multirow[b]{2}{*}{ Body fluid balance } & Unbalance & 62 & 55,4 & 50 & 44,6 & 112 & 100 & \multirow[b]{2}{*}{0,005} & 5,77 \\
\hline & Balance & 24 & 22,2 & 84 & 77,8 & 108 & 100 & & $2,79-11,33$ \\
\hline \multirow{2}{*}{ Urination frequency } & Less & 51 & 40,8 & 74 & 59,2 & 125 & 100 & \multirow{2}{*}{0,551} & 1,18 \\
\hline & Enough & 35 & 36,8 & 60 & 63,2 & 95 & 100 & & $0,68-2,05$ \\
\hline
\end{tabular}




\section{Job Factors Related to Crystalluria}

The research found that from the six job factors variables, there are none of them having a significant statistical relationship because of $\mathrm{P}$-value or all variables less than 0.05 . However, the variable heat needs more attention because the average temperatures index work area reaches to $28,16^{\circ} \mathrm{C}$. (Table 7,8 ). Based on the measurement of wet-bulb globe temperature at eight sampling points using Questemp 34, the result is some work area has a value exceeding threshold limit value (TLV) (Table 9).

Table 7. Overview of Respondents Distribution by Job Factor: Work Period, Heat and Exposure Interval

\begin{tabular}{lccccc}
\hline \multicolumn{1}{c}{ Variable } & Crystalluria & Mean & $\begin{array}{c}\text { Std. } \\
\text { Deviation }\end{array}$ & $\begin{array}{c}\text { Std. Error } \\
\text { Mean }\end{array}$ & $\begin{array}{c}\text { P- } \\
\text { Value }\end{array}$ \\
\hline \multirow{2}{*}{ Work Period (year) } & $(+)$ & 8,17 & 3,4 & 0,4 & 0,788 \\
& $(-)$ & 8,04 & 3,9 & 0,3 & \\
\cline { 2 - 6 } Heat $\left({ }^{\circ} \mathrm{C}\right)$ & $(+)$ & 28,16 & 0,3 & 0,1 & 0,230 \\
& $(-)$ & 28,23 & 0,3 & 0,1 & \\
Exposure Interval (month) & $(+)$ & 317,31 & 48,4 & 5,2 & 0,175 \\
& $(-)$ & 304,81 & 75,9 & 6,6 & \\
\hline
\end{tabular}

Tabel 8. Overview of Respondents Distribution by Job Type, Work Shift, and Work Area

\begin{tabular}{|c|c|c|c|c|c|c|c|c|c|}
\hline \multirow{3}{*}{ Characteristic } & \multirow{3}{*}{ Kategori } & \multicolumn{4}{|c|}{ Crystalluria } & \multirow{2}{*}{\multicolumn{2}{|c|}{ Total }} & \multirow{3}{*}{ P-value } & \multirow{3}{*}{$\begin{array}{c}\text { OR 95\% } \\
\text { CI }\end{array}$} \\
\hline & & \multicolumn{2}{|c|}{$(+)$} & \multicolumn{2}{|c|}{ No } & & & & \\
\hline & & $\mathrm{N}$ & $\%$ & $\mathrm{~N}$ & $\%$ & $\mathrm{~N}$ & $\%$ & & \\
\hline \multirow{2}{*}{ Job Type } & Sedentary & 20 & 51,3 & 19 & 48,7 & 39 & 100 & \multirow{2}{*}{0,085} & 1,834 \\
\hline & Non-Sedentary & 66 & 36,5 & 115 & 63,5 & 181 & 100 & & $\begin{array}{c}0,914- \\
3,683 \\
\end{array}$ \\
\hline \multirow{3}{*}{ Work Shift } & Shift A & 53 & 40,2 & 79 & 59,8 & 132 & 100 & \multirow{3}{*}{0,840} & 0,911 \\
\hline & Shift B & 17 & 35,4 & 31 & 64,6 & 48 & 100 & & $\begin{array}{c}0,581- \\
1,429\end{array}$ \\
\hline & Non Shift & 16 & 40 & 24 & 60 & 40 & 100 & & \\
\hline \multirow{3}{*}{ Work Area } & Body 1 & 47 & 41,2 & 67 & 58,8 & 114 & 100 & \multirow{3}{*}{0,722} & 1,321 \\
\hline & Body 2 & 25 & 38,5 & 40 & 61,5 & 65 & 100 & & $\begin{array}{c}0,832- \\
2,097\end{array}$ \\
\hline & BQC & 14 & 34,1 & 27 & 65,9 & 41 & 100 & & \\
\hline
\end{tabular}


Tabel 9. Wet-Bulb Globe Temperature Result

\begin{tabular}{clcccccc}
\hline $\begin{array}{c}\text { Sampling } \\
\text { Location }\end{array}$ & Area & $\begin{array}{c}\text { Sk } \\
\left({ }^{\mathbf{0}} \mathbf{C}\right)\end{array}$ & $\begin{array}{c}\text { Sba } \\
\left({ }^{\mathbf{0}} \mathbf{C}\right)\end{array}$ & $\begin{array}{c}\text { Sg } \\
\left({ }^{\mathbf{0}} \mathbf{C}\right)\end{array}$ & $\begin{array}{c}\mathbf{R h} \\
(\mathbf{\%})\end{array}$ & ISBB & NAB \\
\hline \multirow{3}{*}{ Body 1 } & Under front & 30,7 & 27,4 & 31 & 65,7 & $\mathbf{2 8}$ & 28 \\
& Underbody & 31 & 27,5 & 31,4 & 65,7 & $\mathbf{2 8 , 5}$ & 28 \\
& Main body & 30,1 & 27,5 & 30,8 & 64,9 & $\mathbf{2 8}$ & 28 \\
& Metal finish & 31,4 & 27,3 & 31,5 & 69 & $\mathbf{2 7 , 8}$ & 28 \\
\cline { 2 - 7 } Body 2 & Under front & 30 & 26,7 & 30,6 & 73 & $\mathbf{2 8}$ & 28 \\
& Underbody & 31,7 & 27,4 & 32,0 & 70 & $\mathbf{2 8 , 4}$ & 28 \\
& Main body & 30,8 & 27,1 & 31,2 & 71 & $\mathbf{2 7 , 9}$ & 28 \\
& Metal finish & 30,9 & 26,9 & 31,1 & 70 & $\mathbf{2 8}$ & 28 \\
\hline
\end{tabular}

\section{Conclusion}

Of the ten types of variables examined individual factors, there are three variables of individual factors that have a statistically significant relation to the case of crystalluria. There are body mass index, body fluid balance, and food consumption with high purine. As well, the variable factor of six occupations studied, there are no variables that have a statistically significant relation to the case of crystalluria. But the heat temperature in the work area must get more attention because the result of wet-bulb globe temperature measurement is excessed TLV.

\section{References}

[1] Daudon, M. \& Frochot, V.: Crystalluria. Clinical Chemistry and Laboratory Medicine (CCLM), 53(s2), pp.1479-1487. (2015)

[2] Penniston, K.: Citric Acid and Kidney Stone. (2014)

[3] Departemen Kesehatan Jakarta. : Laporan riset kesehatan dasar 2013. Jakarta: Badan Penelitian dan Pengembangan Kesehatan Kementerian Kesehatan Republik Indonesia, Jakarta. (2013)

[4] Dano, A.A.Z., Rahim, M.R. \& Muis, M..: Factors Related to the Occurrence of the Crystallization of Urine on the Employee Section of the Furnace Process Plant Departement PT. Vale Indonesia Tbk. Sorowako., pp.1-9. (2014)

[5] Tanagho, E.A. \& McAninch, J.W.: Smith's General Urology 17th ed. E. A. Tanagho \& J. W. McAninch, eds., California: Mc Graw Hill Medical. (2004)

[6] Elliot, J.S. \& Rabinowitz, I.N.: Calcium Oxalate Crystalluria: Crystal Size in Urine. J Urol, 123, p.324. (1980)

[7] Fogazzi, G. \& Garigali, G.: The Urinary Sediment. A new Approach to Urinary Sediment Examination. Elsevier. (2013)

[8] Fauziah, A.N.: Hubungan Suhu Lingkungan Kerja (Heat Stress) dengan Faktor-Faktor Terbentuknya Kristal Asam Urat Urin pada Pekerja Pabrik PT. Maruki Internasional Indonesia. Universitas Muhammadiyah. (2013)

[9] Tawatsupa, B.: Association Between Occupational Heat Stress and Kidney Disease Among 37.816 Worker in the Thai Cohort Study (TCS). Journal of Epidemiology, 22(3), pp.251-260. (2012) 
[10] Sulistiyowati, R., Setiani, O. \& Nurjazuli, N.: Faktor Risiko Yang Berhubungan Dengan Kejadian Kristal Batu Saluran Kemihdi Desa Mrisi Kecamatan Tanggungharjo Kabupaten Grobogan. Jurnal Kesehatan Lingkungan Indonesia, 12(2), pp.99 - 105. (2013)

[11] Purnomo, B.B.: Dasar-dasar Urology, Jakarta: Sagung Seto. (2011)

[12] Daudon, M., Bouzidi, H. \& Bazin, D.: Composition and morphology of phosphate stones and their relation with etiology. Urol Res, 38, pp.67-459. (2010)

[13] Kenefick, R.. \& Sawka, M.: Hydration at the Work Site. Journal of the American College of Nutrition, 26(05), pp.597 - 603. (2007)

[14] Bladder and Bowel Foundation: What is normal urinary frequency? NHS. (2014)

[15] Soemarko, D.S.: Pengaruh Lingkungan Kerja Panas terhadap Kristalisasi Asam Urat Urin pada Pekerja di Binatu, Dapur Utama dan Restoran Hotel X, Jakarta, Jakarta. (1997)

[16] Tazzoli, V. \& Domeneghetti, C.: The crystal structures of whewellite and weddellite: reexamination and comparison. American Mineralogist, 65, pp.327-334. (1980)

[17] Kartini, E. \& Nugroho, L.H.: Bentuk, Distribusi Dan Kerapatan Kristal Kalsium Oksalat Pada Berbagai Sayuran Daun. Chimera, 3(1). (1998)

[18] Chandra, A.: Efek Oksalat bagi Kesehatan. (2011)

[19] Gunawan, I.: Diet Rendah Purin Atasi Asam Urat. detikcom. (2013)

[20] Sugiyono,: Metode Penelitian Kombinasi (Mix Methods) 1st ed., Bandung: AlfaBeta. (2014)

[21] Cheung, L: Healthy Weight: Maintain, Don't Gain. Harvard School of Public Health. (2012)

[22] Badan Standardisasi Nasional. Air Minum Dalam Kemasan, Indonesia. (2006)

[23] World Health Organization.: Chlorine in Drinking-water M. Sheffer, ed., Geneva: Marketing and Dissemination, World Health Organization. (2003)

[24] Setyawati, M.: Hubungan Pekerjaan Aktivitas Rendah (Sedentary Work) dengan Kristal Kalsium Oksalat Urin pada Pegawai Negeri Kantor X di Jakarta [Tesis]., Depok: Fakultas kesehatan Masyarakat Universitas Indoesia. (2005)

[25] Kementerian Tenaga Kerja dan Transmigrasi:, Nilai Ambang Batas Faktor Fisika dan Faktor Kimia Di Tempat Kerja, Indonesia: Permenakertrans. (2011) 